University of Nebraska - Lincoln

DigitalCommons@University of Nebraska - Lincoln

Publications from USDA-ARS / UNL Faculty

U.S. Department of Agriculture: Agricultural

Research Service, Lincoln, Nebraska

1996

Registration of 'Shawnee' Switchgrass

Kenneth P. Vogel

University of Nebraska-Lincoln, kvogel1@unl.edu

A. A. Hopkins

Oklahoma State University

K. J. Moore

USDA-ARS

K. D. Johnson

Purdue University

I. T. Carlson

lowa State University

Follow this and additional works at: https://digitalcommons.unl.edu/usdaarsfacpub

Vogel, Kenneth P.; Hopkins, A. A.; Moore, K. J.; Johnson, K. D.; and Carlson, I. T., "Registration of 'Shawnee' Switchgrass" (1996). Publications from USDA-ARS / UNL Faculty. 1895.

https://digitalcommons.unl.edu/usdaarsfacpub/1895

This Article is brought to you for free and open access by the U.S. Department of Agriculture: Agricultural Research Service, Lincoln, Nebraska at DigitalCommons@University of Nebraska - Lincoln. It has been accepted for inclusion in Publications from USDA-ARS / UNL Faculty by an authorized administrator of DigitalCommons@University of Nebraska - Lincoln. 


\section{Registration of 'Shawnee' Switchgrass}

'Shawnee' switchgrass (Panicum virgatum L.) (Reg. no. CV-181, PI 591824) was released on 13 July 1995 by the USDA-ARS, the Agricultural Research Division of the University of NebraskaLincoln, the USDA-NRCS, the Iowa Agriculture Experiment Station, and the Purdue Agricultural Research Program. The cultivar was developed in cooperative research by the USDA-ARS and the University of Nebraska at the University of Nebraska Agricultural Research and Development Center at Mead, using plant germplasm from the Elsberry Plant Materials Center, USDA-NRCS. Shawnee was evaluated in cooperative trials with the USDA-ARS, the University of Nebraska, Iowa State University, and Purdue University.

Shawnee was developed from a single cycle of restricted, stratified mass selection using the cultivar Cave-in-Rock (1) as the base population. In 1984, a 960-plant, space-transplanted selection nursery was established at the Nebraska Agricultural Research and Development Center using greenhouse-grown seedlings. In 1985, one-third of the plants were visually selected for agronomic traits including vigor, leafiness, and absence of diseases and were harvested to determine forage yield. Forage samples from harvested plants were analyzed for in vitro dry matter digestibility (IVDMD). Seventy-eight plants were selected for polycrossing in the spring of 1988 using a selection index that gave equal weight to forage yield and high IVDMD. The selected plants also had good persistence and low disease incidence and severity relative to the base population. Two ramets of each of the selected plants were transplanted into a completely randomized, space-planted polycross nursery. Seed harvested from the polycross nursery was used in evaluation trials. The polycross nursery is also the breeder seed field for the cultivar.

Replicated space-planted and solid stand or sward yield trials were established in 1990 at Mead, NE; Ames, IA; and West Lafayette, IN $(2,3)$. The evaluation trials were sampled for IVDMD at a vegetative (E3-E4) stage (5) and at panicle emergence, and were harvested for forage yield at panicle emergence and after a killing frost. Compared with Cave-in-Rock, Shawnee had higher IVDMD $(P=0.10)$ at the vegetative stage at Mead, NE, and West Lafayette, IN, in the space-planted trials. In the same trials, Shawnee had higher forage yields and reproductive stage IVDMD than Cave-in-Rock at all sites, but the differences were not statistically significant. In the sward plots, both cultivars had similar forage yields averaged over locations. In sward trials at three locations, Shawnee had significantly higher IVDMD $(P=0.05)$ than Cave-inRock at both the vegetative and reproductive stages, averaging 16 and $13 \mathrm{~g} \mathrm{~kg}^{-1}$ higher, respectively. It was $2 \mathrm{~d}$ later in maturity than Cave-in-Rock. Shawnee was similar to the high-IVDMD cultivar Trailblazer in vegetative-stage IVDMD, but averaged $18 \mathrm{~g}$ $\mathrm{kg}^{-1}$ higher in IVDMD at the reproductive stage of growth. In sward trials, Shawnee had significantly greater forage yields than Trailblazer averaged over the three Midwestern locations when harvested at panicle emergence $(P=0.15)$ and had significantly $(P=$ 0.05 ) greater regrowth yields (i.e., the harvest after a killing frost). In trials conducted in Arkansas by the Arkansas Agricultural Experiment Station, Shawnee had higher or equivalent yields to Cavein-Rock and had significantly $(P=0.05)$ higher yields than Trailblazer over a 2-yr period (4). The justification for the release of Shawnee is its improved forage quality as measured by IVDMD in comparison with Cave-in-Rock and improved forage yield in comparison with Trailblazer. It is named after the Shawnee National Forest in southern Illinois, which is near the location where the germplasm for the cultivar was originally collected.

Shawnee is adapted to USDA plant hardiness zones 5,6 , and 7 east of $100^{\circ} \mathrm{W}$ longitude. Shawnee is an upland, octoploid $(2 n$ $=8 x=72$ ) switchgrass. Seed propagation of Shawnee is restricted to two generations of increase from breeder seed, one each of foundation and certified seed. Breeder seed (Syn 1) is maintained by the cooperative USDA-ARS and University of Nebraska grass breeding project at Lincoln, NE. Foundation seed will be maintained and distributed by the Foundation Seed Division of the University of Nebraska according to allocation policies of the University of Nebraska. The USDA-ARS and USDA-NRCS have no seed for distribution.

K. P. VOGEL,* A. A. HOPKINS, K. J. MOORE, K. D. JOHNSON, AND I. T. CARLSON (6)

\section{References and Notes}

1. Alderson, J., and W.C. Sharp. 1994. Grass varieties in the United States. USDA Agric. Handb. 170. U.S. Gov. Print. Office, Washington, DC.

2. Hopkins, A.A., K.P. Vogel, K.J. Moore, K.D. Johnson, and I.T. Carlson. 1995. Genotype effects and genotype by environment interactions for traits of elite switchgrass populations. Crop Sci. 35:125-132.

3. Hopkins, A.A., K.P. Vogel, K.J. Moore, K.D. Johnson, and I.T. Carlson. 1995. Genotypic variability and genotype $x$ environment interactions among switchgrass accessions from the Midwestem USA. Crop Sci. 35:565-571.

4. Huneycutt, H. 1994. Forage variety performance test 1992-1993. Ark. Agric. Exp. Stn. Res. Ser. no. 435.

5. Moore, K.J., L.E. Moser, K.P. Vogel, S.S. Waller, B.E. Johnson, and J.F. Pedersen. 1991. Describing and quantifying growth stages of perennial forage grasses. Agron. J. 83:1073-1077.

6. K.P. Vogel, USDA-ARS, 344 Keim Hall, Univ. of Nebraska, P.O. Box 830937, Lincoln, NE 68583-0937; A.A. Hopkins, Dep. of Agronomy, Oklahoma State Univ., Stillwater, OK 74078; K.J. Moore (formerly USDA-ARS, Lincoln, NE) and I.T. Carlson, Dep. of Agronomy, Iowa State Univ.. Ames, IA 50011; and K.D. Johnson, Dep. of Agronomy, Purdue Univ., West Lafayette, IN 47907 . Evaluation trials were funded in part by the U.S. Dep. of Energy's Biomass Fuels Program via the Oak Ridge Natl. Lab. Registration by CSSA. Accepted 30 Apr. 1996. *Corresponding author (Email: agro012@unlvm.unl.edu).

Published in Crop Sci. 36:1713 (1996).

\section{Registration of 'Surrey' Annual Ryegrass}

'Surrey' annual ryegrass (Lolium multiflorum Lam.) (Reg. no. CV180, PI 593651) was developed by the Florida Agricultural Experiment Station, Institute of Food and Agricultural Sciences, University of Florida, Gainesville, FL. Surrey was released by the Florida Agricultural Experiment Station in October 1989 (1).

Surrey was selected from certified 'Marshall' annual ryegrass using four cycles of phenotypic recurrent selection in gridded, spaced-plant nurseries of 24000 to 30000 plants in each selection cycle at the Dairy Research Unit near Gainesville, FL. Selection intensity was about $1.25 \%$ in the first cycle, $2.5 \%$ in the second and third cycles, and $20 \%$ in the fourth cycle. Breeder seed was produced in Oregon from bulked seed from Cycle 4 selections. Plant breeding methods are described in greater detail by Prine (2). Selection criteria were high forage and seed production potential, late maturity, and superior resistance to crown rust (caused by Puccinia coronata Corda). Good natural epiphytotics of crown rust were present during the spring of all four selection cycles. Plants with leaf spot symptoms (caused by Drechslera spp.) or any other type of foliar disease damage were eliminated from the nursery. Freeze damage eliminated about $10 \%$ of the plants in the nursery following severe winter freezes during Cycles 2 (1984) and 3 (1985). Normally, freeze damage is not observed in spaced plants of annual ryegrass at the selection Iocation. Composited seed of selected plants from Cycles 2 and 3 were tested in several southeastern regional ryegrass trials as FL X1984 LR and FL X1985 $L R$, respectively. Surrey was tested in southeastern regional ryegrass trials as either FL X1986 LR (Cycle 4) or Surrey. 